\title{
Capital Change and the Cost of Equity: Evidence from Bulgarian Banks. Is there a Modigliani-Miller offset?
}

\author{
Sophia Kassidova ${ }^{1}$
}

\begin{abstract}
:
This paper studies the cost of equity and capital of three Bulgarian listed banks in the framework of the Modigliani-Miller (MM) theory of capital structure. It measures the impact of an increase in capital ratios on the equity risk (equity beta) of these banks.

It finds that, historically, while more equity results in lower banks' systematic risk no causal relationship can be found between an increase in capital ratios and the predicted by the theory decrease in banks' systematic risk. MM irrelevance argument holds that a decrease in equity risk will lead to a decrease in the shareholders' required (and expected) return on equity and thus offsetting the higher equity (capital) level.
\end{abstract}

Thus, the results cannot find evidence in support of the so-called "Modigliani-Miller" offset.

Keywords: cost of bank capital of Bulgarian banks; equity beta; Modigliani-Miller theorem for banks; cost of equity.

JEL code: G31, G32

\footnotetext{
${ }^{1}$ Ph.D., Candidate University of National and World Economy
} 


\section{Introduction}

This paper will investigate the impact of an increase in equity capital (equity ratios) of three listed on the Bulgaria Stock Exchange-Sofia banks on their cost of equity and cost of capital. It will try to find evidence that capital structure does not affect the overall funding costs of these banks. Some recent literature and related empirical work suggest that the overall cost of capital will remain unchanged despite changes in the capital structure, and specifically following an increase in the equity ratio (regulatory or voluntary-driven). This body of work applies concepts from modern capital structure and asset pricing theory.

The last financial and banking crises that started in 2007-2008 made academics and policy makers initiate a vast regulatory reform in banking with some measures targeting the capital structure. Regulators decided to put a floor under the built-up of leverage (Basel III process) and to introduce hard leverage ratio (the opposite of equity ratio) as a supplementary measure to the risk-based rules (Basel II rules). By requiring banks to use more equity funding, regulators aim to avoid their insolvency and make banks more stable. Unsurprisingly, bankers consider equity costlier than debt, so more of it will increase the weighted average cost of capital.

In this debate one strand of academic thinking brings in the classical concept of the Modigliani-Miller (MM) theorem (1958) which predicts that in a world of perfect and efficient markets and absence of taxes and friction costs, the average cost of capital (pre-tax WACC) is unaffected by the capital structure of the company, i.e. the overall funding costs are not affected by the structure of the various claimants on the company assets. Although equity may be more expensive compared to cheaper debt - as claimed by the bankers' community, the higher average cost should be offset by the lower rates of return on both, equity and debt.

If higher capital levels will increase overall funding costs is very much an empirical concern. This research attempts to address and test this hypothesis by using longterm data for three listed Bulgarian banks. The main objective is to evaluate the MM offset of higher capital requirements on the cost of equity and overall capital of the three banks. Far from complete such an analysis will shed light on the Bulgarian banking sector contribution to the ongoing debate. The analysis is innovative in this respect as it is the first one to test the dependencies among the related factors; to what extent these factors explain the relation between the size of capital, the risk and return and the impact of regulation, as well as the behavior of market participants in evaluating the required return.

The testing period starting from 2006 till end 2016 covers two sub-periods - the first one till 2010 marked by a dynamic stock exchange activity on BSE-Sofia, and the second one after 2010 affected by the introduction of the new post crises banking legislation (Basel 2.5 and Basel 3). 
Another innovative aspect is also the testing of the applicability of widely used theoretical and empirical models such as CAPM (Capital Asset Pricing Model) and WACC (Weighted Average Cost of Capital) for the Bulgarian capital markets, and specifically for the local banks.

Some research finds strong arguments in support of the MM prediction -- it is simply a myth and fallacy that equity capital is expensive as there is no strong positive link between banks holding more equity and having higher cost of funds. Admati et al. (2011) claim more equity and less debt should not be more expensive and thus will not affect banks' cost of capital (equity plus debt). Miles (2012) finds that large increase in bank equity results in small long-run increase in the average cost of banking funding for major UK listed banks. Kashyap (2010) studies the impact of heightened capital requirements for big banks on the price of banking loans and finds no major impact. King (2010) finds only a modest increase in the credit spreads of banks stock prices in major EU countries; de Bandt et al. (2014) find evidence in support of MM offset for five major listed French banks.

There is also evidence in support of the opposite strand -- a reduction in equity beta does not translate to a reduction in the cost of equity. Baker and Wurgler (2013) find a $10 \%$-point increase in the required Tier 1 capital to risk weighted assets ratio would have increased the overall cost of capital by as much as 90 basis points.

The central point of this study is testing whether an increase of capital ratios will decrease the systematic risk of three listed Bulgarian banks thus providing evidence in favor of the MM theorem. The idea is that as bank equity increases (i.e. capital ratio increases) the risk of holding it falls. Rational investors will correctly price the new risk and will reduce the required rate of return. Subsequently, the average cost of capital of bank's funding will stay unchanged as the higher equity in the WACC equation will be offset by the decrease in the expected return (cost) of equity capital.

To test the MM offset the author keeps the stringent assumptions of the MM model. The tax regime and its shield effect will be excluded. Still, the three banks face real world factors - asymmetric information, market frictions, transaction costs, agency arguments and thus it is expected that MM offset may not exactly hold.

A handful recent studies have argued that the banks overall cost of capital can be measured properly. Accepted regulatory and economic capital models return a number for the amount (and price) of capital banks must or may wish to hold. Applying MM capital structure theory to the financing decisions of banks has been proposed as the academic's solution to calculate the required capital. Holding more equity capital became the modern paradigm in the 2007 after crises times as an alternative to regulatory risk-weighted capital calculations. Still some of these studies acknowledge banks are special entities and argue that the role of leverage, taxes and other factors are different in this highly regulated sector from non- 
financial firms (Thalassinos and Thalassinos, 2006; Thalassinos and Politis, 2011; Thalassinos et al., 2010; 2015; Thalassinos and Dafnos, 2015; Liapis et al., 2013; Keisidou et al., 2013; Hanias et al., 2007).

Most of the models agree that the Capital Asset Pricing Model (CAPM) is the correct approach to measure the required rate of return. It correctly measures the cost of equity capital and assesses bank riskiness. King (2010) points that the CAPM method is one most commonly used by practitioners to estimate a firm's cost of equity pointing to surveys by Brunner et al. (1998) and Graham and Harvey (2001). King (2010) uses the CAPM to estimate the real cost of equity for 89 largest public banks located in Canada, France, Germany, Japan, the United Kingdom and the United States.

However, still very little is known about the empirical relevance of the MM capital structure theory and most of the empirical work is based on banks in developed capital markets in Europe and the United States. Without testing the robustness of these findings outside the environment in which they were uncovered, it is hard to determine what these empirical facts will be in less developed capital markets.

For example, much of the talk in the banking industry is concerned that higher capital ratios (CR) will imply significantly higher cost of loans for firms. Testing crudely this presumption for the Bulgarian banks gives little support (Figures 1 and Figure 2) for the years after the 2007 financial crises:

Figure 1: Regulatory CR vs percentage spread b/n business loans rates and 3-month SOFIBOR rate

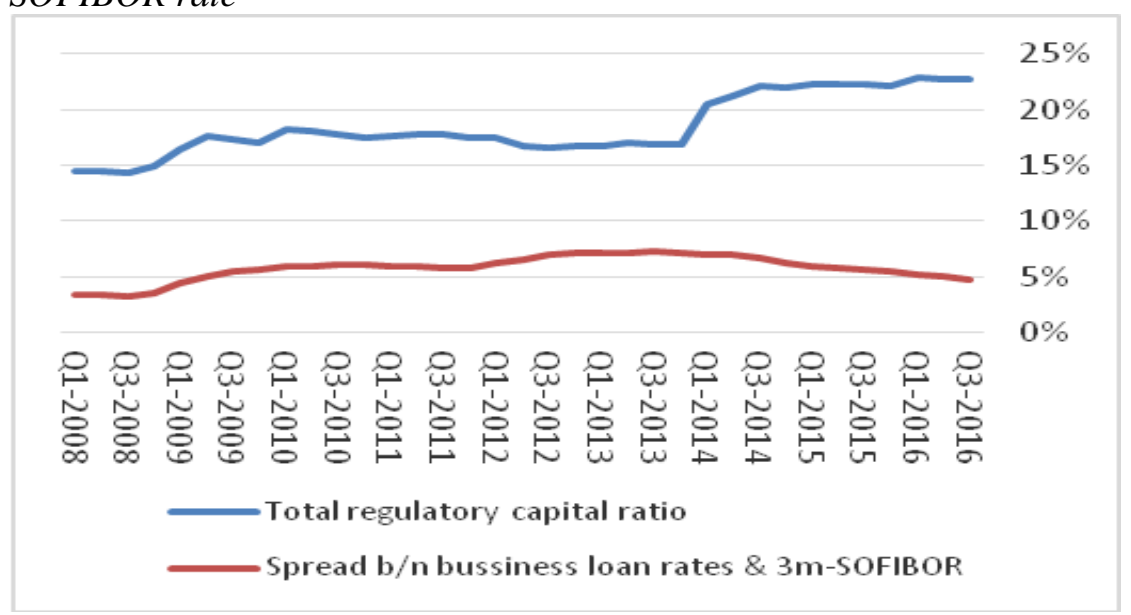

Source: BNB data and the author own calculations

There is little evidence that increase in the CR suppresses GDP growth. Figure 3 gives an eight-year series: no clear relation is evident but an upward correlated trend 
between the average growth of the economy and the capitalization of the banks over the last two years.

\section{Figure 2: Total lending volumes and regulatory capital ratios}

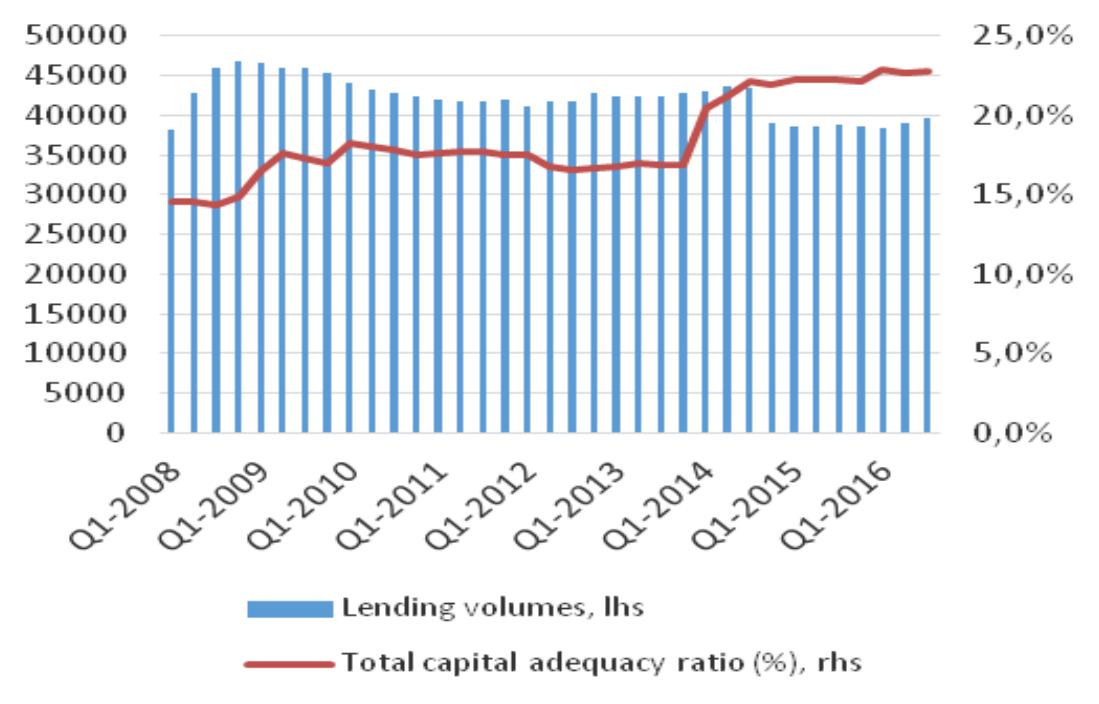

Source: Author's calculations using BNB Financial Supervision reports on the banking system

Figure 3: GDP growth vs. Regulatory capital ratio

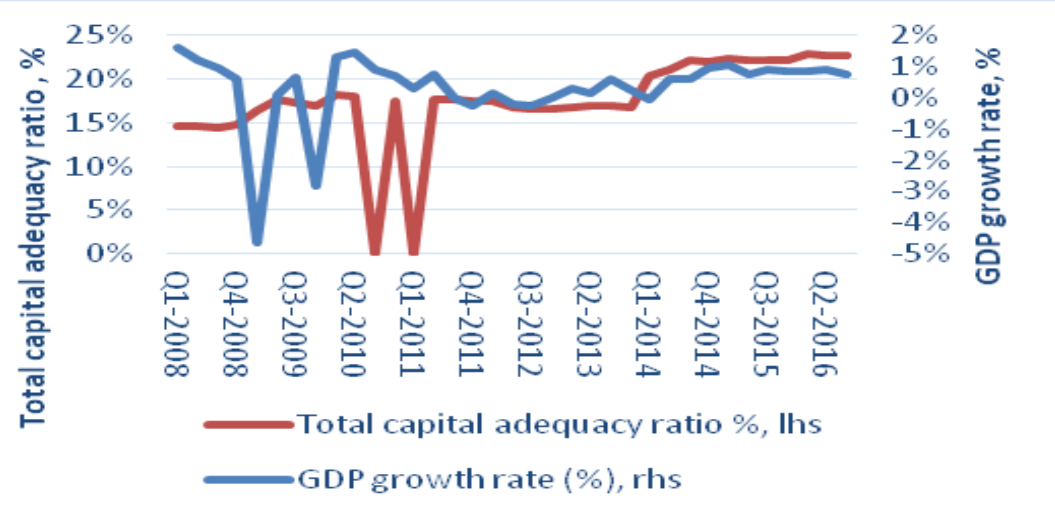

Source: Authors calculations using BNB data on banking system; Ministry of Finance

\section{Method and the empirical model}

The main objective of the analysis is to evaluate the change in capital ratios and the risk-return relationship for the banks in the stock market so to give evidence in the discussion of whether increased equity ratios will make the cost of capital higher. This method borrows from de Brandt et all (2014) methodology which estimates the relationship between banks' cost of capital (WACC) and an increase in equity 
(capital ratio) by using the CAPM and MM I proposition. The CAPM is used to estimate the new required return on equity $(\mathrm{CoE})$ given a change in $\mathrm{CR}$ and a related change in the beta equity ( $\beta$ equity).

Equation (1):

$$
E\left(R_{i, t}\right)=R_{f}+\beta_{k, t} \times\left[E\left(R_{m, t}\right)-R_{f}\right]
$$

Where $\beta_{k, t}$ is the correlation between the bank i's equity return ( $\beta$ equity) and the market return; $R f$ is the risk-free rate of return and the term $\left[E\left(R_{m, t}\right)-R_{f}\right]$ is the excess equity market return.

What is referred to the MM argument is that the left hand-side of equation (2) below does not change when equity ratio (CR) increases. The method simulates this increase on the $\mathrm{CoE}$ which is then used in the WACC formula to estimate how banks' total cost of capital changes or off-sets the increase in the level of capital.

Equation 1:

$$
W A C C=R_{e q} \times \frac{\text { Eqity }}{\text { Total assets }}+R_{f} * \frac{\text { Debt }}{\text { Total assets }}
$$

This methodology relies on the logical argument of the MM propositions. As bank capital increases investors will expect a decrease in bank's stock price volatility and will require lower return based only on the systematic risk they cannot diversify. To measure empirically the link the analysis continues with regressing the change in beta on the change in CR. The baseline model is:

Equation 3:

$\Delta \beta_{i, t}=a_{i}+\gamma * \Delta X_{i, t-1}+\sum_{p=2008}^{2016} Y_{p}+\varepsilon_{i, t}$

Where:

$$
\begin{array}{cl}
\varepsilon_{i, t} & \text { is the disturbance term; } \\
\beta_{i, t}-\beta_{i, t-1} & \text { is a measure of change in beta } \\
\alpha_{i} & \text { is constant bank specific effect } \\
\Delta X_{i, t 1}=\Delta X_{i, t-1}-\Delta X_{i, t-2} & \text { is a measure of change in CR with one period lag to avoid } \\
\sum^{2016} & \text { endogenity } \\
\hline
\end{array}
$$




\section{Data, banks, price returns and betas}

The analysis employs a dataset which combines individual price returns for the three banks listed on the BSE-Sofia, their accounting capital ratios and the returns on the stock market SOFIX15 index (used as a proxy for the market portfolio in the CAPM formula) from Q1 2009 through Q3 2016. The primary source of the banks' stock prices is the BSE-Sofia; other public information sources are used for macroeconomic indicators and banking industry data.

The analysis starts with an estimation of the historical equity betas ( $\beta$ equity) using the daily stock market returns (prices) of each bank together with the returns for the SOFIX15 index. The banks in the analysis are FIB (First Investment Bank), BACB (Bulgarian American-Credit Bank) and CCB (Central Cooperative Bank). For each bank its $\beta$ equity is calculated by regressing its daily stock returns on the daily SOFIX returns for every three-month period of the eight years' time series.

Figure 4: Average beta and accounting capital ratios $(C R)$ for the three banks

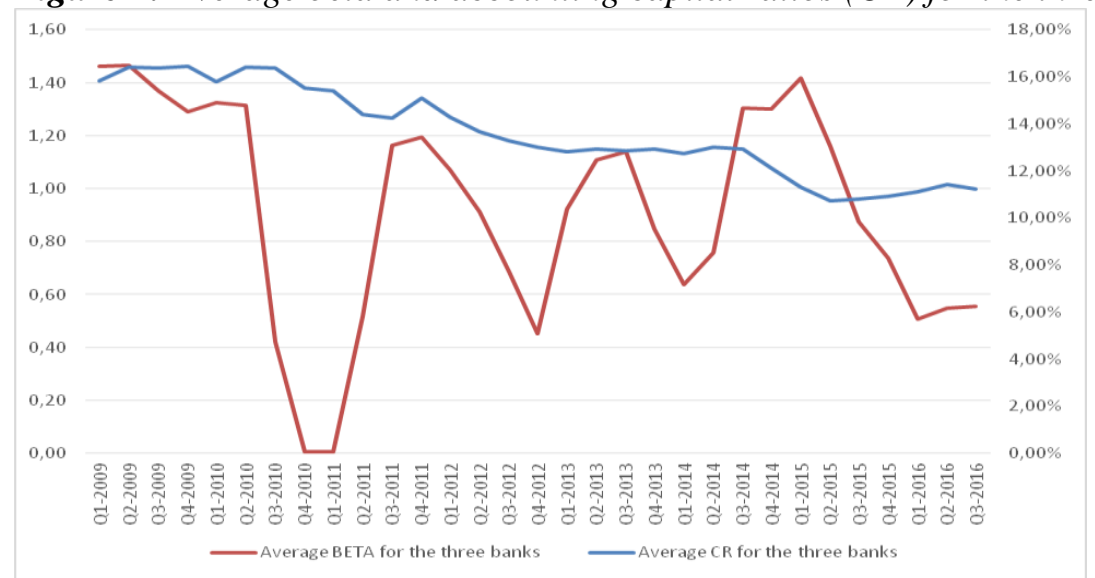

Source: BNB Financial Supervision reports; author's own calculations

\section{Capital Ratios}

The analysis continues with computing the accounting capital ratios (CR) for each bank using the national central bank's (Bulgarian National Bank) public dataset. The CR is equal to the sum of the annual balance sheet equity capital and reserves above the total assets of the bank.

Table 1 shows the descriptive statistics for the two variables - beta and accounting CR. The average beta equals 0.93 meaning that banks' equity is less volatile to market fluctuations. The average beta was not initially influenced by the 2007 crises but in the following years when its effects were felt in the local stock exchange market (Figure 4). 
Table 1: Descriptive statistics for beta and accounting capital ratios (CR)

\begin{tabular}{lllll}
\hline Variable & $\mathrm{N}$ & Mean & Median & SD \\
\hline Beta & 33 & 0.93 & 0.92 & 0.02 \\
CR $(\%)$ & 33 & 0.14 & 0.13 & 0.40
\end{tabular}

Note: This table presents main descriptive statistics for the period 2009 - 2016. Beta is estimated using the SOFIX15 index as the market return. CR is computed as book equity over book total assets. Data frequency is quarterly.

Figure 5: Average accounting capital ratio for the three banks

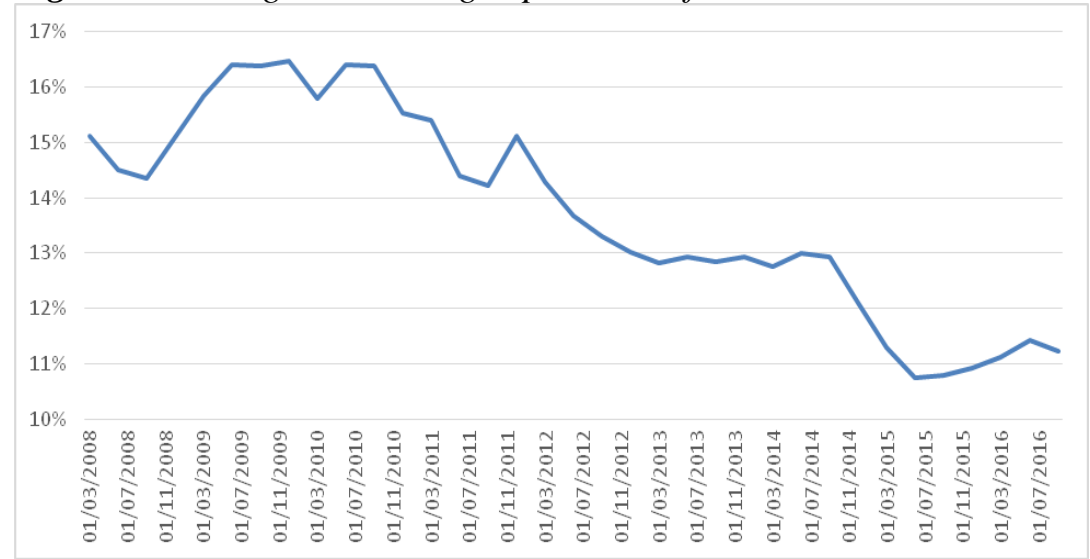

Source: BNB Financial Supervision reports; author's own calculations

Accounting CR are traditionally very high $-13.6 \%$. (compared to an average of $4.11 \%$ for the French banks for the same period, de Brand et al, 2014). They start falling in the aftermath of the crises when more persistent and long-term effects hit the real economy, increased the stock of non-performing loans and wiped out the profits of the banks.

Figure 4 for betas and Figure 5 for the average accounting CR exhibit a fluctuating trend which suggests the series might be non-stationary. The analysis does not include a unit root test to test for this but to cope with the issue, as proposed by de Brandt (2014), it works with the first-difference of the values between each subsequent time interval but not with the data on levels.

To estimate the link between the CR and cost of capital the analysis matches the estimated $\beta$ equity with accounting CRs. It employs accounting CR rather than regulatory capital ratios which are different and do not align with the MM framework balance sheet proportions. By regressing the change in the estimated equity betas for each bank on each bank capital ratio, the model assesses whether $\mathrm{CR}$ affects the risk of equity. It is expected the estimated association to be negative. Figure 6 gives the scatter plot of the values of change in equity $\beta$ against change in banks' CR (the correlation coefficient). 


\section{Figure 6: Scatter plot for the correlation coefficient}

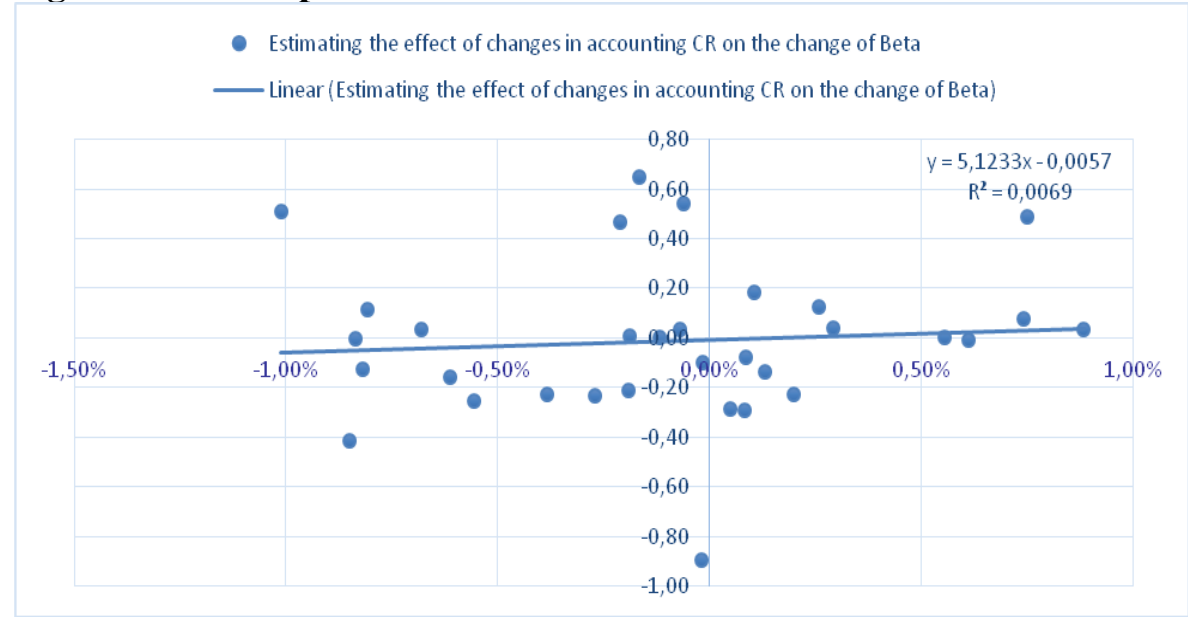

Against expectations, the correlation coefficient is 0.065 with a positive sign and insignificantly small. It shows no association between change in betas and change in CR for the observed period.

\section{Results and analysis}

The model considers only the effect of capitalization of banks and no other restructuring, supervisory or management decisions are included.

Table 2: First difference: Beta and accounting capital ratio

\begin{tabular}{|c|c|}
\hline \multicolumn{2}{|c|}{$\Delta$ Beta equity } \\
\hline Variables & Regression OLS: \\
\hline$\triangle \mathrm{CR}$ & 0.0473 \\
\hline Intercept & $(0.00001)$ \\
\hline Observations & 32 \\
\hline R Square & 0.0078 \\
\hline N. of banks & 3 \\
\hline
\end{tabular}

Note: This table reports regression estimates of a change in equity beta on a change on accounting capital ratios. Beta is estimated on a quarterly frequency using the SOFIX15 index for the market return. CR is computed as book equity over book total assets.

Significance is at 5 percent.

The model gives estimates for the OLS of the unknown parameters reported in table 2. As pointed above the results are not in line with the predictions of the theory and they are not in support of the theory as the findings of the French (de Brandt et al, 2014) and UK banks (Miles, 2012). The estimate is positive but statistically insignificant (the $\mathrm{R}$ square is only 0.023 ) and thus not meaningful. The estimated model has a poor fit and does not explain whether the amount of capital held by banks has an impact on the riskiness of their equity. One possible explanation can 
be that the model estimates suggest market participants do not consider the change in CR to assess the riskiness of a bank equity capital.

\section{Predictions: capital ratios and cost of equity}

In efficient markets with no frictions and transaction costs an increase in capital ratios will be associated with lower equity betas and lower returns on equity capital. The results of this analysis cannot be related to the predictions of the MM theorem. While the estimates look illogical there may be other endogenous facts and academic literature that explain these but not covered by the author.

A possible explanation may be found in Baker and Wurgler (2013) who point that cross-sectional relationship between capital structure and betas cannot be used to measure the causality effect of an increase in capital. Too, de Brand et al find no evidence that regulatory $\mathrm{CR}$ influences riskiness. The reason is a possible nonnormality of the distribution of the variables which might be solved by a logspecification of the model.

The results of this study require further investigation and application of more rigorous econometric techniques and tests. A more sophisticated model for examples can model changes in bank $\mathrm{CoC}$ as a function of changes and levels of balance sheet and macro financial variables as suggested by an IMF paper (2014).

\subsection{Model simulation of the MM offset}

The results from the first stage of the empirical analysis do not support the theoretical argument of the MM theorem, specifically that changes in the capital structure must result in changes to the return on equity (and the return on debt) that ensure that return on assets is unchanged. It is why a simulation of such an offset effect is pointless. It cannot estimate the magnitude of a fall in the related $\mathrm{CoE}$ and CoC (WACC). If the result was affirmative, based on the CAPM calculation it would have implied that the expected return on equity falls when the capital increase. The next step would have been to calculate the return on equity from historical betas as follows:

Equation 5:

$$
R_{e q}=R_{f}+\beta_{e q} *\left(R_{m}-R_{f}\right)
$$

So that expected return on equity equals $2.8 \%+0.79 * 9.2 \%=10.07 \%$, where the risk-free rate equals the average 10-year local government bonds yields, the beta equity is the estimated average historical beta for the four banks and the equity risk premium is the rate given by Damodaran (2015). The WACC is calculated by using equation (2): WACC $=13.7 \% * 10.07 \%+86.4 \% * 2.8 \%$, where the $\mathrm{CR}$ is the estimated sample mean for the three banks and the debt is assumed to be risk-free. Next, from the baseline model: 


$$
\Delta R_{e q}=\Delta \beta_{e q} \times\left(R_{m}-R_{f}\right)=\hat{\gamma} \cdot \Delta X_{i, t-1} \times\left(R_{m}-R_{f}\right)
$$

a new return on equity would have been calculated, given an increase in CR, where $\gamma^{\wedge}$ is the estimated coefficient in the first-difference regression of change in beta equity on change in CR. Recalculating WACC with the new RoE and a hypothetical doubling of the $\mathrm{CR}$, for example, and comparing to the WACC calculated when no increase in $\mathrm{CR}$ occurred would have given a stylized quantification of the MM offset.

\section{Conclusion}

This analysis's main ideas are: firstly, and most importantly to test the MM capital structure irrelevance proposition for three listed Bulgarian banks. While other empirical and theoretical papers give such evidence, the expected qualification stated in the beginning could not be repeated.

Regulators are concerned with the stability of banks but also with the impact regulation has on banks' costs of funds. Following the unexpectedly severe effect the recent financial crises caused on the run on banks (Acharya, 2009), academics look for a new paradigm to regulate banks. A few suggest looking to the classical capital structure theory to find the optimal debt-equity ratio that will ensure banks are resilient to panics.

In a market with no taxes and imperfections MM theory (1958) predicts that holding more equity will not increase the cost of capital as its beta and risk will fall leaving the pretax WACC unchanged. As leverage decreases and firms become less risky investors and shareholders will correctly price their holdings and will require less return. To what extent there is an offset on banks WACC from the effect of using more equity? Though it is logical it is not self-evident and should be simulated and computed using real bank data.

This analysis finds that data on capital ratios as proxy for equity and equity beta do not match the theory in the case of the selected three Bulgarian bank firms. The increase in equity does not affect its beta and the estimates of the regression coefficients are statistically insignificant. One possible interpretation might be that reducing equity beta will not reduce the cost of equity. Another one might be that the high capitalization of the Bulgarian banks (compared to an average CR of $4.5 \%$ for French banks over the same period) does not correlate with its systematic risk. Such a correlation and causal effect might exist at much lower levels of CR which for obvious reasons cannot be tested in this study.

Other explanations that relate to the specificities of the Bulgarian stock market can be borrowed from a study of Donchev (2016) on the application of asset pricing models for stocks traded on the Bulgarian stock market. Donchev finds that pricing of expected returns on stocks by using CAPM is acceptable with certain limitations 
- the model is dependent on the market capitalization of the company, the overall stock market liquidity (which in the case of the BSE-Sofia is low compared to mature markets) as well as the overall level of economic development of Bulgaria.

The behavior of the stock market participants who do not respond by pricing efficiently the change in the levels of CR of banks may influence this "stickiness" of beta in a relationship that might not be linear. Other imperfections in the markets like regulatory capture, the political clientele and the incentives of bankers are variables which are present in real life though are distant deviation from the MM theory assumptions.

The causal link between leverage and beta is not assured as it could also run in the opposite direction. For instance, a bank manager may first set a target risk profile and then decide on the leverage that is consistent with the target. More generally banks with different risk profiles (i.e. riskier loan books) may choose endogenously different capital structures by applying economic capital concept to model it.

Furthermore, the choice of control variables attempts to capture other factors that can affect banks' risk which are specific to each bank: return on assets (to account for overall bank profitability), total assets (to account for size) and risk-weighted assets (to control for a regulatory measure of balance sheet risk). Additional limitations of the leverage ratio are that it is a crude calculation as it does not distinguish different assets by their riskiness and this way may punish banks which hold highly liquid, high-quality assets. The bank asset risk is also borne by the debt holders and such a "risk-sharing" among equity and debt flattens the empirical relationship between capital ratios and beta.

\section{References:}

Admati, A.R., De Marzo, P.M., Helwig, M.F. 2011. Fallacies, Irrelevant facts, and Myths in the Discussion of Capital Regulation: Why bank Equity is Not Expensive, https://gsbapps.stanford.edu/researchpapers/library/RP2065R1\&86.pdf

Acharya, V. and Richardson, M. 2009. Causes of the Financial Crises. Critical Review, July.

Babihuga, R. and Spaltro, M. 2014. Bank Funding Costs for International Banks, IMF Working Paper.

Baker, M. and Wurgler, J. 2013. Do Strict Capital Requirements Raise the Cost of Capital? Banking Regulation and the low Risk Anomaly. National Bureau of Economic Research, Working Paper 19018.

Damodaran, A. 2015. Equity Risk Premiums (ERP): Determinants, Estimation and Implications, http://people.stern.nyu.edu/adamodar/

ECB Financial Stability Review. 2011. Common Equity Capital, Banks’ Riskiness and Required Return on Equity, IV Special Features, www.ecb.europa.eu

Hanias, P.M., Curtis, G.P. and Thalassinos, E.J. 2007. Non-linear dynamics and chaos: The case of the price indicator at the Athens Stock Exchange. International Research Journal of Finance and Economics, 11(1), 154-163.

Hellwig, M. 2010. Capital regulation after the crisis: Business as usual? Working Paper Max 
Planck Institute for Research on Collective Goods, http://hdl.handle.net/10419/57491.

Kashyap, A., Stein, J., and Hanson, S. 2010. An analysis of the impact of "substantially heightened" capital requirements on large financial institutions, University of Chicago and Harvard Working Paper, May, http://chifl.shufe.edu.cn/upload/htmleditor/File/120916100241.pdf

Keisidou, E., Sarigiannidis, L., Maditinos, D. and Thalassinos, I.E. 2013. Customer satisfaction, loyalty and financial performance: A holistic approach of the Greek banking sector in Marketing Intelligence and Planning, 31(4), 259-288, Emerald Group Publishing Ltd., DOI: 10.1108/IJBM-11-2012-0114.

King, M.R. 2010. Mapping capital and liquidity requirements to bank lending spreads, BIS working papers, N. 324.

King, M. 2010. The cost of equity for global banks: a CAPM perspective from 1990 to 2009, BIS Quarterly Review, September.

Liapis, K., Rovolis, A., Galanos, C. and Thalassinos, I.E. 2013. The Clusters of Economic Similarities between EU Countries: A View Under Recent Financial and Debt Crisis. European Research Studies Journal, 16(1), 41-66.

Mayers, S. 1984. The Capital Structure Puzzle. Journal of Finance, 39(3), 574-592.

Miles, D., Yang J. and Marcheggiano, J. 2013. Optimal Bank Capital, The Economic Journal 123.

Miller, M. 1995. Do the MM propositions apply to banks? Journal of Banking and Finance, 19, 483-489.

Modigliani, F. and Miller, M. 1958. The Cost of capital, corporation finance and the theory of investment. American Economic Review, 48(3), 261-297.

Thalassinos, E., Thalassinos, P. 2006. Stock Markets' Integration Analysis. European Research Studies Journal, 9(3-4), 3-14.

Thalassinos, I.E. and Politis, D.E. 2011. International Stock Markets: A Co-integration Analysis. European Research Studies Journal, 14(4), 113-129.

Thalassinos, I.E., Deceanu, L. and Pintea, M. 2010. New Dimensions of Country Risk in the Context of the Current Crisis: A Case Study for Romania and Greece. European Research Studies Journal, 13(3), 225-236.

Thalassinos, I.E., Stamatopoulos, D.T. and Thalassinos, E.P. 2015. The European Sovereign Debt Crisis and the Role of Credit Swaps. Chapter book in The WSPC Handbook of Futures Markets (eds) W. T. Ziemba and A.G. Malliaris, in memory of Late Milton Miller (Nobel 1990) World Scientific Handbook in Financial Economic Series Vol. 5, Chapter 20, pp. 605-639, ISBN: 978-981-4566-91-9, (doi: 10.1142/9789814566926_0020).

Thalassinos, I.E. and Dafnos, G. 2015. EMU and the process of European integration: Southern Europe's economic challenges and the need for revisiting EMU's institutional framework. Chapter book in Societies in Transition: Economic, Political and Security Transformations in Contemporary Europe, 15-37, Springer International Publishing, DOI: 10.1007/978-3-319-13814-5_2. 